\title{
PENGEMBANGAN MEDIA EVALUASI PEMBELAJARAN SEJARAH BERBASIS GOOGLE FORMULIR DI SMA N 1 PRAMBANAN
}

Oleh: Dwi Purwati, Alifi Nur Prasetia Nugroho

SMA N 1 Prambanan, Universitas Negeri Yogyakarta

Email: $\underline{\text { dwipurwati6@gmail.com, alifinur.pn@uny.ac.id }}$

\begin{abstract}
ABSTARCT
The research aimed to find out: (1) to produce history evaluation media based on google form; (2) know the level the effectiveness of google form as a evaluation teaching history in SMA N 1 Prambanan. This research use research and development method which adapted with the design development ADDIE; (1) analysis model; (2) design model; (3) development; (4) implementation; and (5) evaluation. The study population was high school in SMA N 1 Prambanan. The instruments that used to collect the data were observation sheets, interview and test achievement. The research result showed that History media evaluation based on Google Form in History with feasibility level according to the assessment by material experts was obtained by $79,8 \%$ which was category of feasible, assessment by media experts was obtained by 78,5\% which was category of feasible, and assessment by learning experts was obtained by $86,3 \%$ which was category of very feasible. The limited trial result obtained percentage by $86,3 \%$ which was category of very feasible. The result of extensive trial obtained percentage by $83,6 \%$ which was category of very feasible.
\end{abstract}

Keyword: Google form, media evaluation, history

\section{PENDAHULUAN}

Saat ini masyarakat hidup dalam era digital di mana teknologi berkembang dengan sangat pesat. Kemajuan teknologi yang begitu cepat ini memberikan kemudahan dalam kehidupan masyarakat. Teknologi informasi dan komunikasi (TIK) adalah elemen yang perubahannya paling cepat. Perkembangan TIK ini tidak bisa lepas dari semakin luasnya jaringan internet di Indonesia. Saat ini kita bisa dengan mudah mengakses berbagai informasi dalam waktu yang singkat. Perkembangan teknologi informasi dan komunikasi ini juga memberi dampak perubahan bagi kehidupan masyarakat, termasuk pada dunia pendidikan.

Peserta didik yang dihadapi guru zaman sekarang jauh berbeda dengan masa sebelumnya. Peserta didik sekarang merupakan anak-anak generasi $\mathrm{Z}$, yaitu generasi yang lahir dan tumbuh di era internet. Mereka melek teknologi sehingga mempunyai ruang leluasa untuk menggapai dunia dan impiannya. (Kompas, 20 Maret 2018). Oleh sebab itu, guru sebagai salah satu komponen penting dalam dunia pendidikan dituntut untuk melek teknologi dan dapat memanfaatkannya dalam pembelajaran untuk mencetak generasi yang mampu menjawab tantangan global.

Guru pada era teknologi saat ini tidak lagi sebagai sumber utama pembelajaran karena informasi berkembang dengan begitu cepat dan peserta didik mampu mengaksesnya dengan begitu mudah, bahkan bisa jadi lebih cepat dari gurunya. Guru yang hanya mampu memberikan informasi tentang materi pelajaran kepada peserta didik lambat laun akan tergantikan oleh teknologi. Guru harus mampu merancang pembelajaran yang tidak hanya seketar tranfer of knowlege tetapi justru lebih mengarah pada transfer of values. Sebab, 
yang menjadi persoalan pada era saat ini bukan lagi tentang cara memanfaatkan teknologi, tetapi bagaimana cara memanfaatkan teknologi tersebut dengan penuh tanggung jawab.

Pembelajaran adalah sebuah proses atau cara yang dilakukan agar seseorang melakukan kegiatan belajar. Kegiatan pembelajaran adalah proses yang mengandung hubungan timbal balik antara siswa dengan guru. Dalam proses ini guru dan siswa melakukan interaksi yang bersifat edukatif. Kegiatan pembelajaran dapat dilakukan di dalam kelas maupun di luar kelas. Interaksi edukatif tidak hanya sebatas dalam penyampaian nilai pengetahuan tetapi juga nilai-nilai kehidupan.

Efektivitas pembelajaran dapat tercapai tergantung kemampuan guru dalam manajemen pembelajaran. Pembelajaran dikatakan efektif jika tujuan dari pembelajaran tersebut dapat tercapai. Agar pembelajaran menjadi efektif, guru dituntut untuk mampu memilih strategi, metode, dan media yang tepat sesuai dengan bahan yang akan disampaikan. Kemampuan guru dalam merancang dan melaksanakan pembelajaran sangat menentukan apakah pembelajaran tersebut akan efektif atau tidak.

Dalam kurikulum 2013, pemerintah menuntut guru untuk mampu mengintegrasikan pembelajaran dengan penggunaan teknologi informasi dan komunikasi (TIK). Guru harus menguasai TIK dan menerapkannya dalam proses belajar mengajar sehingga peserta didik dapat mengakses berbagai pengetahuan dari berbagai sumber yang ada. Guru saat ini seharusnya tidak lagi menjadi sentral kelas, berdiri di depan kelas menjelaskan materi. Guru harus menjadi inspirator, berada di tengah-tengah peserta didik, mendampingi, dan membimbing peserta didik yang mencari informasi dari gawai yang dimiliki.

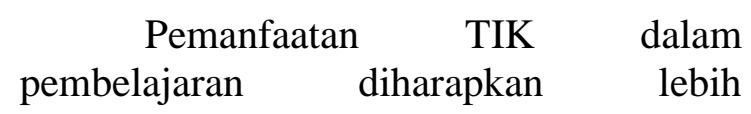
meningkatkan pemahamannya terhadap materi yang dipelajari. Sebab, dengan memanfaatkan teknologi pembelajaran akan lebih menarik. Pemanfaatan teknologi dalam dunia pendidikan tidak hanya berhenti pada proses mencari dan menyampaikan pengetahuan saja. Teknologi juga harus digunakan dalam proses evaluasi pembelajaran. Penggunaan media berbasis TIK dalam evaluasi pembelajaran diharapkan mampu meningkatkan hasil evaluasi. Pemanfaatan teknologi ini diharapkan dapat menumbuhkan rasa senang dan ketertarikan peserta didik terhadap evaluasi pembelajaran.

Evaluasi pembelajaran adalah rangkaian dari proses pembelajaran. Setiap guru wajib melakukan evaluasi dalam pembelajaran yang dilakukannya. Menurut Zainal Arifin (2009) fungsi dari evaluasi adalah mengetahui kedudukan peserta didik, mengetahui taraf kesiapan peserta didik menempuh program, membantu guru memberikan bimbingan, dan memberi laporan kemajuan peserta didik. Guru wajib melakukan evaluasi dalam proses pembelajaran yang telah dilaksanakan. Hasil evaluasi dapat digunakan sebagai tolok ukur keberhasilan pembelajaran yang sudah dilaksanakan sekaligus menjadi pertimbangan menentukan pembelajaran berikutnya.

Seorang guru dapat menentukan bentuk evaluasi yang akan dilakukan pada proses pembelajarannya. Bentuk evaluasi pembelajaran tidak selalu dalam bentuk ujian. Evaluasi pembelajaran dapat dilakukan dalam bentuk memberi tugas, mengadakan diskusi, tanya jawab, atau mengemukakan pendapat. Ujian hanya salah satu bentuk evaluasi namun bentuk ini paling sering digunakan di dunia pendidikan. Bentuk ujian sebagai salah satu alat evaluasi pembelajaran pun sangat 
beragam. Ada ujian tertulis, ujian lisan, atau ujian berbasis komputer.

Pada era teknologi seperti saat ini, bentuk ujian mulai beralih dari yang dulunya menggunakan kertas ujian atau Paper Based Test (PBT) menjadi evaluasi berbasis TIK atau yang lebih dikenal dengan Computer Based Test (CBT). Sebelum penggunaan sistem CBT pendidikan di Indonesia telah memanfaatkan komputer sebagai alat bantu pembuatan evaluasi dan pengoreksian lembar jawab. Soal dibagikan dalam bentuk kertas dan peserta didik mengisi jawabannya pada lembar kerja komputer (LJK) menggunakan pensil atau bolpoin. Sistem ini masih digunakan sampai saat ini pada sebagian besar pendidikan di Indonesia. Sistem ini memang cukup efisien karena guru tidak perlu mengoreksi satu per satu lembar jawaban peserta didik.

Pengenalan sistem CBT di Indonesia sejatinya sudah dilakukan sejak tahun 2007. Beberapa perguruan tinggi sudah menggunakan sistem ini dalam menyelenggarakan ujian masuk bagi mahasiswa baru walaupun fasilitas komputer yang digunakan untuk CBT pada saat itu masih sangat terbatas. Pada tahun 2014, pemerintah juga menggunakan sistem ini dalam seleksi nasional penerimaan calon pegawai negeri sipil. Jimoh, Abdul Jake, dkk (2012) mengatakan menggunakan Computer Based Test (CBT) sebagai media evaluasi dianggap lebih efisien dan praktis jika dibanding dengan sistem PBT. Sistem CBT juga lebih efisien dari segi waktu, tenaga, dan biaya penyusunannya.

Pemerintah Indonesia sudah mengaplikasikan evaluasi pembelajaran CBT ini dalam sistem ujian nasional sejak tahun 2015. Ujian Nasional Berbasis Komputer (UNBK) dilakukan secara Online menggunakan komputer dan jaringan internet yang tersambung ke server pusat. Pelaksanaan Ujian Nasional berbasis TIK adalah salah satu upaya pemerintah mengurangi angka kecurangan selama pelaksanaan Ujian Nasional. Menurut berita yang dimuat beberapa koran nasional, seperti Kompas, Republika, dan Tempo, pada tahun 2015 menunjukkan bahwa angka kecurangan pada pelaksanaan ujian nasional pada jenjang SMA mengalami penurunan yang signifikan. Pada tahun sebelumnya tercatat terdapat 200 laporan terkait kecurangan pelaksanaan ujian nasional. Pada tahun 2015, saat semakin banyak sekolah yang melaksanakan UNBK, laporan tersebut turun menjadi 100 laporan saja.

Konsep evaluasi pembelajaran berbasis TIK seharusnya bisa diterapkan dalam evaluasi pembelajaran harian di kelas, bukan hanya dalam Ujian Nasional. Penilaian harian berbasis TIK adalah upaya mengenalkan dan membiasakan peserta didik dengan sistem UNBK sehingga secara teknis peserta didik akan jauh lebih siap menghadapi UNBK di kelas XII nanti. Pelaksanaan evaluasi pembelajaran berbasis TIK saat ini bukan lagi hal yang sulit, mengingat teknologi informatika begitu dekat dengan kehidupan sehari-hari baik bagi peserta didik maupun bagi guru.

Pengembangan media evaluasi berbasis TIK mulai banyak dilakukan. Penawaran aplikasi latihan soal secara Online bisa dengan mudah ditemukan di internet saat ini. Beberapa aplikasi bahkan bisa diakses dengan mudah menggunakan smartphone android. Salah satu yang dapat dimanfaatkan sebagai media evaluasi berbasis TIK adalah Google Formulir. Google Formulir adalah bagian dari komponen Google Docs yang disediakan oleh raksasa teknologi Google. Google Formulir adalah software yang dapat diakses secara gratis dan cukup mudah dalam pengoperasiannya.

Pengembangan

media pembelajaran di sekolah ternyata masih sangat minim dan masih konvensional, 
termasuk pada media evaluasi. Guru-guru di SMA Negeri 1 Prambanan masih merasa ragu untuk menggunakan media evaluasi dengan model $C B T$ dan memilih melakukan evaluasi berbasis kertas. Walaupun sarana dan prasarana sekolah untuk melakukan evaluasi pembelajaran dengan model $C B T$ sangat mendukung. Sekolah sudah mempunyai jaringan wifi dan laboratorium komputer yang dapat dimanfaatkan dalam pembelajaran. Hampir semua peserta didik pun mempunyai smartphone yang mendukung untuk melaksanakan evaluasi pembelajaran model $C B T$.

Berdasarkan masalah di atas peneliti ingin menyuguhkan alternatif media evaluasi pembelajaran baru yang berbasis TIK menggunakan Google formulir. Penelitian ini bertujuan untuk (1) Menjelaskan prosedur pembuatan media evaluasi pembelajaran menggunakan Google formulir; (2) Mengetahui efektivitas menggunakan Google formulir sebagai media evaluasi pembelajaran pada mata pelajaran sejarah di SMA Negeri 1 Prambanan.

\section{METODE PENELITIAN}

Berdasarkan masalah yang menjadi fokus dalam penelitian ini, yang menekankan pada uji produk, maka metode yang tepat untuk digunakan adalah metode penelitian dan pengembangan (research and developmen/ $R \& D$ ). Tatik Sutarti (2017) menjelaskan penelitian R\&D adalah penelitian yang digunakan untuk mengembangkan dan memvalidasi produk pendidikan, bukan untuk menguji teori. Model yang digunakan dalam penelitian ini adalah model ADDIE Reiser and Molled.

Adapun tahapan dalam penelitian R\&D ini adalah (1) tahap analisis model yaitu mengidentifikasi obyek penelitian; (2) tahap desain model yaitu merancang media evaluasi yang akan digunakan; (3) tahap development, yaitu mempersiapkan bahan pengajaran; (4) tahap implementasi; dan (5) tahap evaluasi. Sedangkan untuk mengukur efektivitas media digunakan uji $\mathrm{T}$ Independent Sample Test.

Penelitian ini diawali dengan melakukan observasi terhadap pembelajaran sejarah di kelas XI IPS SMA Negeri 1 Prambanan. Kelas XI IPS1 dengan jumlah 24 peserta didik sebagai kelompok kontrol dan kelas XI IPS1 dengan jumlah 25 peserta didik sebagai kelompok eksperimen. Sebelum instrumen penelitian diberikan kepada kelas penelitian, terlebih dahulu dilakukan uji validasi dan reliabilitas pada instrumen penelitian.

\section{PEMBAHASAN DAN HASIL PENELITIAN}

Hasil observasi yang dilakukan di SMA Negeri 1 Prambanan diketahui bahwa dalam melakukan evaluasi pembelajaran sejarah, guru masih menggunakan media konvensional berbasis kertas. Pelaksanaan evaluasi pembelajaran dilakukan dalam dua sesi, sesi pertama untuk peserta didik dengan nomor absen ganjil dan sesi kedua untuk peserta didik dengan nomor absen genap. Guru membuat dua soal dengan kode A dan B. Dalam evaluasi seperti ini, terdapat kelemahan yaitu guru harus mengeluarkan lebih banyak energi untuk menyusun soal evaluasi karena harus membuat dua paket soal dan menggandakannya sejumlah peserta didik. Sedangkan peserta didik yang mendapat sesi dua akan lebih diuntungkan karena mendapat ekstra waktu untuk belajar dibandingkan peserta didik pada sesi pertama.

Berdasarkan hasil observasi tersebut, peneliti menawarkan media evaluasi pembelajaran berbasis komputer menggunakan software Google formulir. Google formulir adalah sebuah aplikasi yang dikembangkan Google untuk membuat sebuah survei dan kuesioner yang dikembang. Google formulir adalah 
bagian dari Google doc, sebuah aplikasi rintisan Google untuk membuat, mengedit, dan menyimpan dokumen. Formulir yang dibuat dalam Google formulir secara otomatis akan tersimpan di Google drive dan dapat dengan mudah dibagikan kepada siapa saja. ( $G$ Suite by Google cloud, Formulir). Walaupun aplikasi ini dibranding untuk membuat survei dan kuesioner, Google formulir juga bisa digunakan untuk membuat media evaluasi pembelajaran.

Google formulir dipilih sebagai media evaluasi karena aplikasi ini dapat diakses dengan mudah oleh semua orang. Pada Google formulir guru tidak perlu membuat soal evaluasi dalam beberapa paket karena Google secara otomatis akan mengacak urutan soal dan opsi jawaban. Untuk soal pilihan ganda dan isian singkat, Google formulir dapat mengoreksi jawaban secara otomatis dan peserta didik dapat mengetahui nilai hasil evaluasi pembelajaran setelah selesai mengerjakan. Google formulir akan secara otomatis menyimpan hasil pekerjaan peserta didik dan guru dapat mengunduh dalam bentuk dokumen Excel lengkap dengan nilai yang diperoleh dan jawaban yang dipilih oleh peserta didik.

Peserta didik masa kini sangat akrab dengan teknologi informatika, terutama smartphone. Kondisi ini sangat mendukung penggunaan Google formulir sebagai media evaluasi. Google formulir dapat dengan mudah diakses oleh semua pihak, baik menggunakan perangkat komputer maupun menggunakan smartphone. Jika peserta didik tidak mungkin menggunakan laboratorium komputer, maka evaluasi tetap bisa dilaksanakan menggunakan smartphone yang dimiliki peserta didik.

Pengembangan Google Formulir sebagai media evaluasi Pembelajaran

Dalam Undang-undang No. 23 tahun 2017 tentang sistem pendidikan nasional, dijelaskan bahwa evaluasi pembelajaran dilakukan dalam enam tahap, yaitu (1) Menyusun rencana evaluasi pembelajaran; (2) Melaksanakan evaluasi; (3) Melakukan verifikasi data; (4) Menganalisis data; (5) Melakukan penafsiran dan penarikan kesimpulan; (6) Menindaklanjuti hasil evaluasi. (Kadek Ayu Astiti: 2017). Pada tahap penyusunan rencana evaluasi, guru harus merumuskan tujuan evaluasi dan bentuk evaluasi. Setelah bentuk dan tujuannya dirumuskan, maka guru dapat menyusun kisi-kisi evaluasi dan melanjutkannya pada tahap pembuatan media evaluasi.

Pembuatan Google formulir sebagai media evaluasi pembelajaran tidaklah susah. Tahap pertama adalah pastikan Guru mempunyai akun Google. Saat ini hampir semua guru mempunyai smartphone. Sebagian besar smartphone yang digunakan oleh guru berbasis android, maka guru tentunya sudah mempunyai akun Google. Dalam penggunaan smartphone berbasis android, pengguna diharuskan memiliki akun Google untuk dapat mengakses layanan salah satunya Google formulir. Jika belum mempunyai akun Google, Guru bisa mendaftar melalui https://accounts.google.com/SignUp//.

Guru dapat memulai membuat formulir dengan mengunjungi alamat Google formulir melalui http://www.google.com/int/id_id/forms/ab out/. Setelah masuk ke halaman laman klik tombol "Buka Google Formulir" atau "Go To Google Forms". Tombol tersebut akan membawa masuk ke laman awal Google formulir. Laman awal tersebut memuat judul formulir, pengaturan latar formulir, pertanyaan, tanggapan dan pengaturan model formulir. Jika akun Google Guru belum aktif, maka saat mengunjungi laman tersebut, guru akan diminta login aku Google terlebih dahulu. 


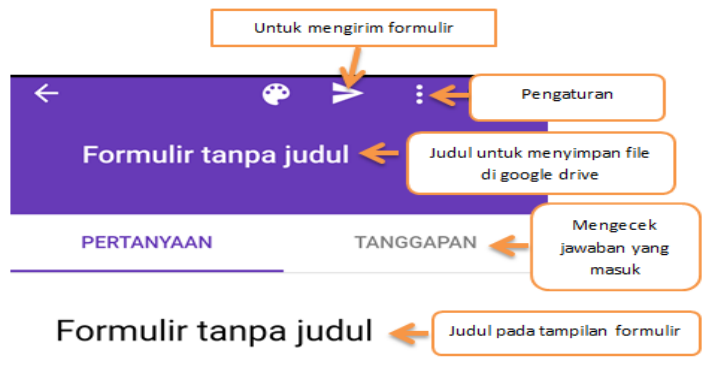

Gambar 1. Tampilan Google formulir

Saat masuk ke laman awal Google formulir isikan judul formulir pada bagian "Formulir tanpa judul". Dalam laman terdapat dua bagian yang mengharuskan menulis judul formulir. Judul formulir bagian atas akan menjadi nama file dari formulir tersebut, sedangkan yang bawah akan muncul sebagai judul dari formulir tersebut saat diakses oleh peserta didik. File dari formulir yang dibuat akan secara otomatis tersimpan di Google Drive. Jika ingin mengedit soal bisa langsung membuka file tersebut di Google Drive sehingga jauh lebih praktis.

Sebelum masuk ke tahap pembuatan soal, formulir dalam Google formulir harus diatur agar bisa digunakan sebagai media evaluasi. Pengaturan ini harus dilakukan sebab Google formulir sejatinya dikembangkan untuk mengumpulkan data survei. Untuk mengatur formulir, masuklah ke bagian setelan atau setting. Pada bagian setelah terdapat tiga menu, yaitu umum, presentasi, dan kuis. Bagian kanan atas terdapat tombol simpan untuk menyimpan pengaturan dan tombol silang (X) untuk kembali ke laman awal.

Setingan umum digunakan untuk mengatur saat responden, dalam hal ini peserta didik yang akan mengerjakan evaluasi, pada awal masuk ke formulir. Pada bagian ini terdapat empat menu. Pertama, kumpulkan alamat email. Jika menu ini dicentang maka setiap siswa yang akan mengerjakan soal di Google formulir harus memasukkan alamat emailnya terlebih dahulu. Jika tidak memasukkan alamat email maka peserta didik tidak bisa mengerjakan soal evaluasi. Kedua, batas ke 1 tanggapan. Jika menu ini diaktifkan maka satu alamat email atau satu akun Google hanya bisa digunakan untuk satu kali mengerjakan soal. Ketiga, edit setelah mengirim. Menu ini memberikan akses kepada peserta didik untuk mengubah jawabannya setelah mengirimnya. Untuk evaluasi pembelajaran sebaiknya menu ini dinon-aktifkan. Terakhir, menu lihat diagram dan respons tes. Jika menu ini diaktifkan masa peserta didik dapat melihat hasil evaluasi pembelajaran dari peserta didik lain yang sudah terlebih dahulu mengirimkan jawaban.

Setting presentasi secara umum digunakan untuk mengatur tampilan soal pada formulir. Pada bagian ini terdapat tiga menu, yaitu aktifkan bilah kemajuan, acak urutan pertanyaan, dan tampilkan link untuk menyerahkan tanggapan lain. Menu acak urutan pertanyaan sebaiknya diaktifkan agar pertanyaan dapat di acak secara otomatis oleh sistem. Sehingga peserta didik satu dengan yang lain tidak mengerjakan soal yang sama dalam waktu yang bersamaan. Sedangkan untuk menu tampilkan link untuk menyerahkan tanggapan bisa digunakan jika memang soal evaluasi mengharuskan melampirkan sebuah file yang besar, seperti video.

Setting kuis digunakan untuk menjadikan formulir sebagai media membuat kuis. Dalam evaluasi pembelajaran dengan media Google formulir, setting ini yang akan digunakan. Dalam setting ini terdapat tiga menu, yaitu jadikan ini sebagai kuis, opsi kuis, dan responden dapat melihat. Untuk membuat media evaluasi pembelajaran maka menu "jadikan ini sebagai kuis" harus diaktifkan. Jika tidak maka guru tidak dapat membuat kunci jawaban dan bobot penyekoran soal. Menu opsi kuis" berkaitan dengan rilis nilai hasil evaluasi. Jika ingin nilai langsung keluar begitu peserta didik mengirim jawaban maka beri centang pada opsi "segera setelah setiap pengiriman". 
Tetapi jika guru ingin menganalisis nilai terlebih dahulu sebelum diketahui oleh peserta didik, guru hanya perlu mengaktifkan opsi "nanti setelah peninjauan manual". Sedangkan untuk menu "responden dapat melihat" terdapat tiga opsi, yaitu pertanyaan tak terjawab, jawaban yang benar, dan nilai point. Jika setiap opsi dicentang maka setelah mengirim jawaban peserta didik dapat melihat analisis dari soal dan jawaban yang sudah mereka kirim.

Setelah pengaturan awal formulir selesai dilakukan maka guru dapat kembali pada halaman awal Google formulir. Pada halaman awal ketik kalimat pertanyaan. Setelah itu pilihlah bentuk pertanyaannya. Google formulir menawarkan beberapa jenis pertanyaan, seperti jawaban singkat, paragraf, pilihan ganda, kotak centang, atau skala linear. Jenis yang disarankan untuk membuat media evaluasi pembelajaran adalah jawaban singkat, paragraf, atau pilihan ganda. Untuk pertanyaan pertama pada formulir sebagai media evaluasi pembelajaran sebaiknya adalah nama dan kelas peserta didik dengan jenis pertanyaan jawaban singkat sehingga memudahkan dalam merekap hasil evaluasi.

Guru juga dapat membuat variasi soal dengan menyisipkan gambar dalam pertanyaan menggunakan menu "image" bada bagian kanan soal. Gambar dapat dipilih dari file yang dimiliki pada smartphone atau komputer yang digunakan saat membuat soal tersebut. Setelah dipilih, gambar haruslah diunggah ke Google formulir. Gambar juga bisa disisipkan pada opsi jawaban dengan metode yang sama. Sebenarnya jika ingin menyisipkan video, Google telah menyediakannya juga, sayangnya video tidak bisa menyatu dengan soal sehingga jika setting acak soal diaktifkan maka video akan teracak oleh sistem dan terpisah dari soal di bawahnya.
Untuk membuat pertanyaan baru, klik menu bergambar "tambah" pada bagian kanan laman jika membuat formulir dari komputer atau pada bagian bawah laman jika membuatnya menggunakan smartphone. Jika ingin mengedit pertanyaan cukup meletakkan kursor pada soal dan mengekliknya dua kali. Apabila setting pada presentasi untuk acak soal telah diaktifkan, sebaiknya dalam pembuatan soal jangan diberi nomor. Sebab jika diberi nomor soal, saat peserta didik mengakses formulir maka nomor soal akan muncul secara acak dan justru akan mengacaukan tampilan.

Begitu soal selesai dibuat tahap berikutnya adalah membuat opsi jawaban. Tuliskan opsi jawaban pada kolom yang tersedia di bawah pilihan jenis pertanyaan. Selanjutnya "pilih jawaban yang benar" pada bagian kiri bawah pertanyaan. Pada bagian ini guru dapat membuat kunci jawaban dan menentukan skor dari pertanyaan jika dijawab dengan benar. Jika ingin menampilkan opsi secara acak, maka masuk ke menu setting atau pengaturan yang disimbolkan dengan tiga titik di bagian kanan bawah opsi jawaban, kemudian aktifkan menu acak opsi. Sama halnya dengan pertanyaan, jika pilihan "acak opsi" diaktifkan maka sebainya jangan menuliskan abjad opsi (A, B, C, D, E) pada depan opsi.

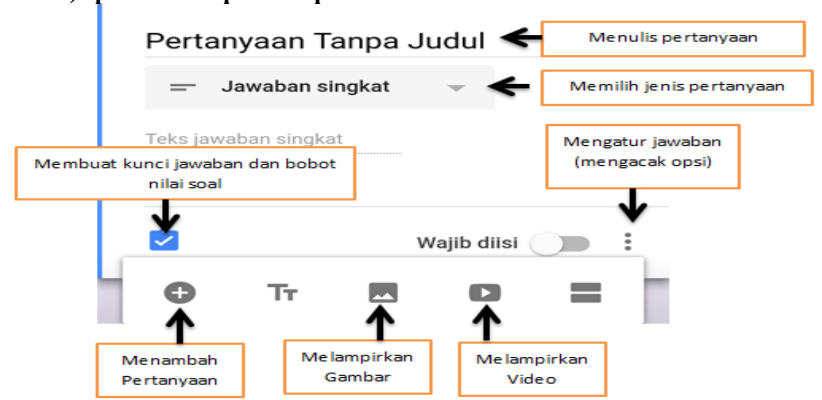

Gambar 2. Tampilan pembuatan soal dalam Google formulir

Adapun cara untuk membagikan soal pada Google formulir adalah dengan klik menu "kirim". Sebelum mengirim formulir guru dapat melihat bentuk soal dengan klik 
menu "pratinjau". Jika soal sudah sesuai maka bisa klik menu "kirim". Google formulir dapat dikirim dalam tiga metode, yaitu email, link, dan html. Jika menggunakan metode email, maka formulir akan dikirimkan ke alamat email yang sudah ditentukan. Jika menggunakan link maka formulir akan dibagikan dengan mengopi link formulir. Link ini dapat dibagikan ke peserta didik melalui aplikasi whatsapp atau line. Metode html digunakan untuk memasang formulir pada blog atau website.

\section{Penilaian Harian I Kelas XI IPS3}

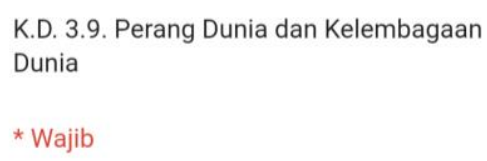

Peserta didik yang akan mengerjakan evaluasi secara Online dapat mengakses soal melalui link yang sudah dibagikan. Formulir pada Google formulir dapat diakses melalui smartphone atau komputer yang terhubung dengan jaringan internet. Untuk menjawab pertanyaan pilihan ganda, peserta didik cukup mengeklik opsi jawaban yang dipilih. Jika pertanyaannya esai atau jawaban singkat, peserta didik cukup mengeklik kolom jawaban dan mengetikkan jawabannya. Setelah soal selesai dikerjakan, peserta didik harus klik menu "kirim" agar jawabannya masuk ke aplikasi. Jika pada setting kuis diaktifkan rilis nilai begitu dikirim, maka nilai evaluasi pembelajaran akan langsung keluar setelah nilai dikirim.

Guru dapat memantau jawaban peserta didik pada menu "tanggapan". Pada menu ini, guru sebagai admin dari formulir yang digunakan sebagai media evaluasi pembelajaran dapat mengetahui berapa jumlah peserta didik yang sudah mengirim jawaban. Pada menu tanggapan, admin dapat mengetahui (1) nama peserta didik yang sudah mengirimkan jawaban , (2) nilai dari masing-masing peserta didik yang sudah mengirim jawaban, (3) sebaran jawaban dari opsi pada setiap soal, dan (4) grafik nilai seluruh peserta didik yang sudah mengirimkan jawaban. Hasil tanggapan juga dapat diunduh dalam bentuk Excel.

Agar soal evaluasi yang dibuat pada Google formulir terjamin kerahasiaannya, maka admin dapat membatasi akses pada soal tersebut. Untuk mengatur tampilan formulir ini, admin dapat masuk ke menu tanggapan lalu pilih menu "menerima tanggapan". Jika menu tersebut diaktifkan maka formulir sebagai media evaluasi pembelajaran dapat diakses, jika dimatikan maka formulir tersebut tidak bisa diakses. Saat menu "menerima tanggapan" dimatikan, admin dapat menulis pesan bagi peserta didik yang mengakses formulir tersebut. Misalnya, "Anda dapat mengerjakan soal ulangan ini pada hari Selasa, tanggal 25 Maret 2018 pada pukul 12.00 WIB sampai dengan pukul 14.00 WIB.

\section{Hasil Penelitian}

Hasil penelitian menunjukkan bahwa tersusunnya evaluasi pembelajaran berbasis Google formulir pada mata pelajaran Sejarah dengan tingkat kelayakan berdasarkan penilaian ahli materi diperoleh persentase sebesar 79,8\% 
termasuk kategori layak, penilaian ahli media diperoleh persentase sebesar 78,5\% termasuk kategori layak, penilaian ahli pembelajaran dengan persentase sebesar $86,3 \%$ termasuk kategori sangat layak. Hasil uji coba terbatas hasil yang diperoleh persentase sebesar 83,6 \% termasuk kategori sangat layak. Hasil uji coba luas diperoleh persentase sebesar 78,7\% termasuk kategori layak. Hasil penelitian menunjukkan bahwa Google formulir layak digunakan sebagai media evaluasi pada pembelajaran sejarah

\section{Evaluasi Media}

Pemanfaatan Google formulir sebagai media evaluasi pembelajaran sebenarnya tidak banyak mengalami kesulitan. Pengembangan aplikasi besutan Google ini juga tidak rumit dan sangat sederhana. Jika dibanding dengan aplikasi evaluasi pembelajaran model CBT yang lain, Google formulir jauh lebih praktis karena tidak perlu meng-instal software. Google formulir juga dapat diakses di segala tempat selama memiliki jaringan internet. Sayangnya pengembangan awal Google formulir sebagai media untuk mengumpulkan data survei dan kuesioner menyebabkan munculnya keterbatasan jika aplikasi ini dimanfaatkan sebagai media evaluasi pembelajaran.

Media evaluasi pembelajaran yang dikembangkan dengan Google formulir belum bisa dilakukan pembatasan waktu pengerjaan soal. Pada umumnya aplikasi CBT mempunyai penunjuk waktu mengerjakan soal yang berjalan mundur, sehingga peserta didik mengetahui sisa waktu yang dimiliki untuk menyelesaikan tes tersebut. Pada media evaluasi pembelajaran yang dikembangkan dengan Google formulir belum terdapat menu tersebut.. Admin hanya bisa membatasi waktu akses terhadap soal tersebut.

Kelemahan kedua adalah tidak ada menu untuk menandai soal mana yang sudah dikerjakan, belum dikerjakan, atau sudah dikerjakan tapi masih ragu-ragu.
Cara untuk menyiasati kelemahan ini adalah mengaktifkan menu "wajib dijawab" pada setiap soal. Saat menu ini aktif maka saat peserta didik akan mengirim jawaban dan terdapat soal yang belum dijawab, formulir tidak bisa dikirim sehingga peserta didik harus mengecek satu per satu soal yang tersedia.

Dalam penelitian ini, peneliti menemukan dua kelemahan tersebut. Sebenarnya kelemahan tersebut dapat diatasi dengan mengintegrasikan Google formulir dengan website. Website tersebut dapat di-setting dengan tampilan seperti pada laman untuk UNBK. Jika ingin mengerjakan soal peserta didik harus mengisi token terlebih dahulu sehingga soal menjadi lebih terjaga kerahasiaannya.

\section{PENUTUP}

Berdasarkan hasil penelitian diketahui bahwa penggunaan Google formulir sebagai alat evaluasi pada pembelajaran sejarah di SMA N 1 Prambanan lebih efektif dan efisien dibanding dengan media konvensional seperti kertas. Bagi guru pembuatan media evaluasi pembelajaran dengan Google formulir cukup mudah dan lebih efisien, baik dari segi biaya, waktu, maupun tenaga. Bagi peserta didik melakukan evaluasi pembelajaran dengan media Google formulir juga lebih menarik dan menyenangkan. Hasil penelitian menunjukkan bahwa evaluasi pembelajaran yang dilakukan menggunakan media Google formulir layak digunakan sebagai media evaluasi pembelajaran.

\section{DAFTAR PUSTAKA}

Admin Google. 2018. G suite by Google cloud, formulir. Diakses pada http://www.google.com/intl/id/for m/about/ pada tanggal 20 Maret 2018. 
Dune, Richard. 1996. Pembelajaran Efektif (terjemah). Jakarta:

Grasindo.

Tatik Sutarti. 2017. Kiat Sukses Meraih Hibah Penelitian Pengembangan. Yogyakarta: Deepublish.

Undang-Undang Sistem Pendidikan Nasional No.20 tahun 2003.

Zaenal Arifin. 2009. Evaluasi Pembelajaran: Prinsip, Teknik, Prosedur. Bandung: Remaja Rosdakarya. 